\title{
Effect of Low Quality Effluent from Wastewater Stabilization Ponds to Receiving Bodies, Case of Kilombero Sugar Ponds and Ruaha River, Tanzania
}

\author{
Magayane Machibya $^{1^{*}}$ and Fredrick Mwanuzi ${ }^{2}$ \\ ${ }^{1}$ Water Resources \& GIS Specialist, ITECO Consult (T) Limited, Dar Es Salaam, Tanzania. \\ ${ }^{2}$ Water Resources Engineering, University of Dar Es Salaam, Tanzania. \\ *Correspondence to Dr. Magayane Machibya, Email: machibya_m@yahoo.com/magayane.machibya@itecoconsult.com
}

Received: 21 December 2005 / Accepted: 31 May 2006 / Published: 30 June 2006

\begin{abstract}
A study was conducted in a sewage system at Kilombero Sugar Company to review its design, configuration, effectiveness and the quality of influent and effluent discharged into the Ruaha river (receiving body). The concern was that, the water in the river, after effluent has joined the river, is used as drinking water by villages located downstream of the river. Strategic sampling at the inlet of the oxidation pond, at the outlet and in the river before and after the effluent has joined the receiving body (river) was undertaken. Samples from each of these locations were taken three times, in the morning, noon and evening. The sample were then analysed in the laboratory using standard methods of water quality analysis. The results showed that the configuration and or the layout of the oxidation ponds (treatment plant) were not in accordance with the acceptable standards. Thus, the $\mathrm{BOD}_{5}$ of the effluent discharged into the receiving body (Ruaha River) was in the order of $41 \mathrm{mg} / \mathrm{l}$ and therefore not meeting several standards as set out both by Tanzanian and international water authorities. The Tanzanian water authorities, for example, requires that the $\mathrm{BOD}_{5}$ of the effluent discharged into receiving bodies be not more that $30 \mathrm{mg} / \mathrm{l}$ while the World Health Organization (WHO) requires that the effluent quality ranges between $10-$ $30 \mathrm{mg} / \mathrm{l}$. The paper concludes that proper design of treatment plants (oxidation ponds) is of outmost importance especially for factories, industries, camps etc located in rural developing countries where drinking water from receiving bodies like rivers and lakes is consumed without thorough treatment. The paper further pinpoint that both owners of treatment plants and water authorities should establish monitoring/management plan such that treatment plants (oxidation ponds) could be reviewed regarding the change on quantity of influent caused by population increase.
\end{abstract}

Keywords: Effluent standard, oxidation ponds, receiving bodies, wastewater.

\section{Introduction}

Sewage can be defined as discharges from domestic and sanitary appliances or simply a complex mixture of materials from varied sources. This complex mixture contains both soluble and insoluble materials [1]. It is under these reasons that sewage from homestead has to be managed before is flushed away into receiving bodies like rivers, lakes and oceans as harmless stuff. Since the mixture is complex, it is usually treated by a mixture of settlement and biological processes. Settlement process permits materials which are suspended in a sewage to settle to the bottom of a container and therefore to be removed from the bulk of the liquid. The longer the materials are retained in the container, the greater the amount of suspended solids that will be able to settle out.
Thus short retention times will only remove the largest particles, while long retention times provide greater solids removal. Biological processes convert materials in the sewage into biological cell materials which can usually be easily settled out from a solution by a settlement process.

Both settlement and biological process can only be achieved with a right design of treatment plants (wastewater stabilization ponds). However, the effectiveness of stabilization ponds will mainly depend among others the configuration and size of the ponds with respect to the sewage discharges [2]. The effectiveness referred here is the ability to treat the influent to a standard (allowable) effluent to be discharged into receiving bodies.

Based on this understanding of sewage systems and their complexity in management and design, the 
Kilombero Sugar Company recently launched a study to review their sewage system in terms of design, configuration, effectiveness and the quality of influent and effluent discharged into the Ruaha River (receiving body). The concern was that the population at the company is increasing and the water in the river, after effluent from oxidation pond has joined the river, is used as raw drinking water by villages located further downstream.

\section{Methods and Materials}

\section{Review of Existing Pond Layout}

Generally there exist two types of waste stabilization pond systems. The Facultative - Maturation System (FM system) and the Anaerobic-Facultative Maturation System (AFM-System). In the absence of the grit chambers and screen, the most layout of the conventional Waste Stabilization Pond (WSP) is given in Figure 1 [2]. Given the waste water discharge, the two systems require different area and configuration for proper functioning.

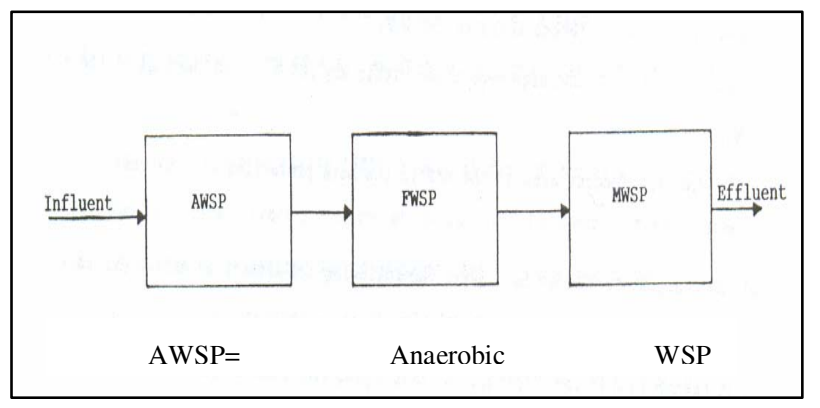

Figure 1: Conventional layout of waste stabilization ponds

The sewerage of the Kilombero Sugar Company (K2 side) consists of a network which gravitate to the pumping station thereafter gravitate to the wastewater stabilization ponds (treatment plant) [2]. The plant consists of a very basic, single series of ponds, one large pond connected to a much smaller pond. Earlier studies by different consultants have referred the first pond as Anaerobic pond and the second one as facultative pond. However, according to the layout and depth requirements the first pond can be regarded as facultative pond and the smaller one to be maturation pond thus a need for the anaerobic pond.

\section{Review of Waste Water Discharges}

For the design and operation of all treatment plants, an accurate knowledge of the sewage flow and sewage characteristics is essential. The daily volume of sewage per capita can vary from less than 501 for a relatively primitive camping site to more than $300 \mathrm{l}$ for an affluent high amenity residential area $[1,5]$.

In order to accurately determine the flow of a particular sewage system, the best method is to measure the flow over a representative time. If this procedure cannot be followed, some less rigorous method has to be adopted [1, 2]. Comparison with a similar site is advantageous, modifying the data in the light of particular circumstances. Often designs are based almost entirely upon educated estimates of flows. Even for cases when estimates are used, it is important to critically assess these design parameters.

During this study, Sewage flow was estimated using two methods. The first method was through use of population data and consideration of peak period and then the average flows were estimated. The second method of estimation made use of electronic flow measuring equipment called Ultrasonic metre. The equipment is capable of measuring both pressurized and non pressurized sewage flows in different piped materials.

\section{Review of Waste Water Quality}

The strength of sewage in an area drained by a sewerage system which permits the inclusion of surface water can be low, with a BOD5 of less than $100 \mathrm{mg} / \mathrm{I}$, while the wastes from chemical closets can have a BOD5 in excess of $1,000 \mathrm{mg} / \mathrm{I}$.

It therefore follows that before a waste water stabilization system is design, the influent and effluent standards need to be fixed to a certain level. In reviewing the Kilombero system it was necessary to investigate the level of quality of both influent and effluent. In addition, the quality of receiving body (the Ruaha river) before and after effluent has joined the river was investigated.

\section{Data Collection and Results}

\section{Pond Layout and Size}

The existing layout and configuration of the Kilombero wastewater stabilization pond probably does not belong into any of the two types of system mentioned above (FMS and AFMS) [2, 3]. The pond has only two chambers, one large $(65 \times 161 \mathrm{~m})$ and another small $(65 \times 25 \mathrm{~m})$. The existing pond calculates an area of $1.2 \mathrm{ha}$. Figure 2 shows the layout of the existing pond.

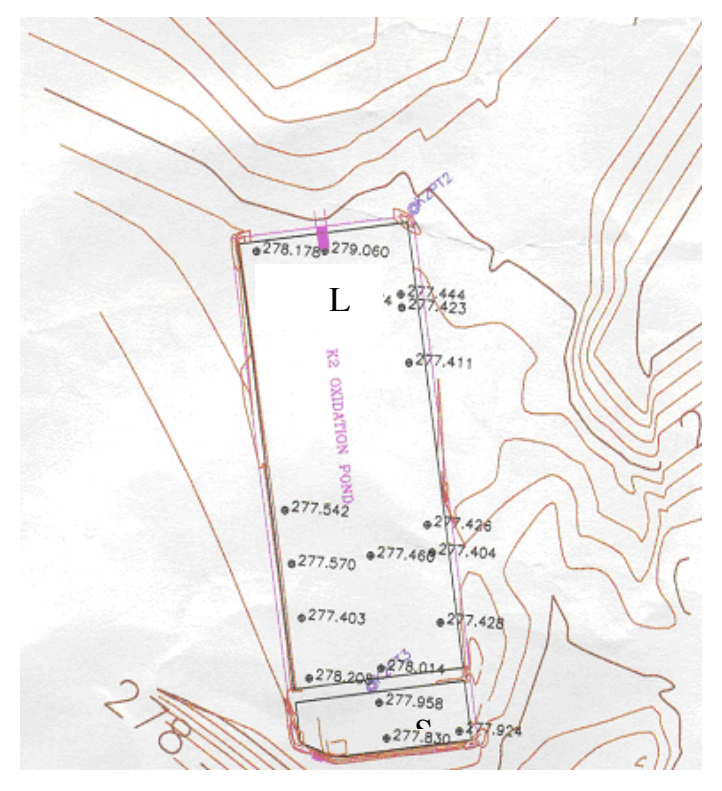

Figure 2: Existing layout of the $\mathrm{K} 2$ pond 


\section{Discharge Data}

Three types of data were collected in order to be able to review the sewage system of the Kilombero sugar company (K2 side). The first key data collected was the waste water discharge from the whole system. The two approaches which were used included the use of the social and quantitative approach where by a population and an estimated waste water discharge of 80 litres per day per capita were used to calculate the discharge. The second approach where special equipment called Ultrasonic meter was used to estimate the flows in the main pipe. The results from the two methods did not differ significantly as $\mathrm{P}=0.61$ which is greater than 0.05 in the ANOVA analysis Table $1(\mathrm{a} \& \mathrm{~b})$.

Table 1(a): Estimated waste discharges to waste stabilization ponds

\begin{tabular}{lcc}
\hline Reading & $\begin{array}{c}\text { Population approach } \\
\left.\text { estimation ( } \mathrm{m}^{3} / \text { day }\right)\end{array}$ & $\begin{array}{c}\text { Ultrasonic } \\
\text { meter readings } \\
\left(\mathrm{m}^{3} / \text { day }\right)\end{array}$ \\
\hline $1^{\text {st }}$ & 600.56 & 600.00 \\
$2^{\text {nd }}$ & 600.56 & 604.18 \\
$3^{\text {rd }}$ & 600.56 & 591.20 \\
\hline Average & 600.56 & 598.46 \\
\hline
\end{tabular}

Table 1(b): ANOVA Analysis on difference of data from the two approaches

\begin{tabular}{lcccccc}
\hline $\begin{array}{l}\text { Source of } \\
\text { Variation }\end{array}$ & $S S$ & $d f$ & $M S$ & $F$ & $P$-value & F crit \\
\hline $\begin{array}{l}\text { Between } \\
\text { Methods }\end{array}$ & 6.62 & 1.00 & 6.62 & 0.30 & 0.61 & 7.71 \\
$\begin{array}{l}\text { Within } \\
\text { Methods }\end{array}$ & 87.80 & 4.00 & 21.95 & & & \\
\hline Total & 94.41 & 5.00 & & & & \\
\hline
\end{tabular}

When the results from the two approaches were compared, the result from the social method showed higher daily discharges $\left(600.56 \mathrm{~m}^{3} /\right.$ day $)$ compared to the ultrasonic meter results which showed $598.46 \mathrm{~m}^{3} /$ day. As it is usual with all designs, the higher parameter was considered during the design stage.

\section{Water Quality Data}

Water samples were taken at the inlet and outlet of the water stabilization ponds in a repetitive ways three times a day (morning, afternoon and evening). In addition water samples were taken from the receiving body (Ruaha River) before and after the effluent joined the river. The sampling locations were as illustrated by Figure 3.

The collected samples were then analyzed in the laboratory using standard procedures [6] as illustrated in Table 2. The results from the analysis in the laboratory, for each of the sample, are presented in Tables 3 and 4.

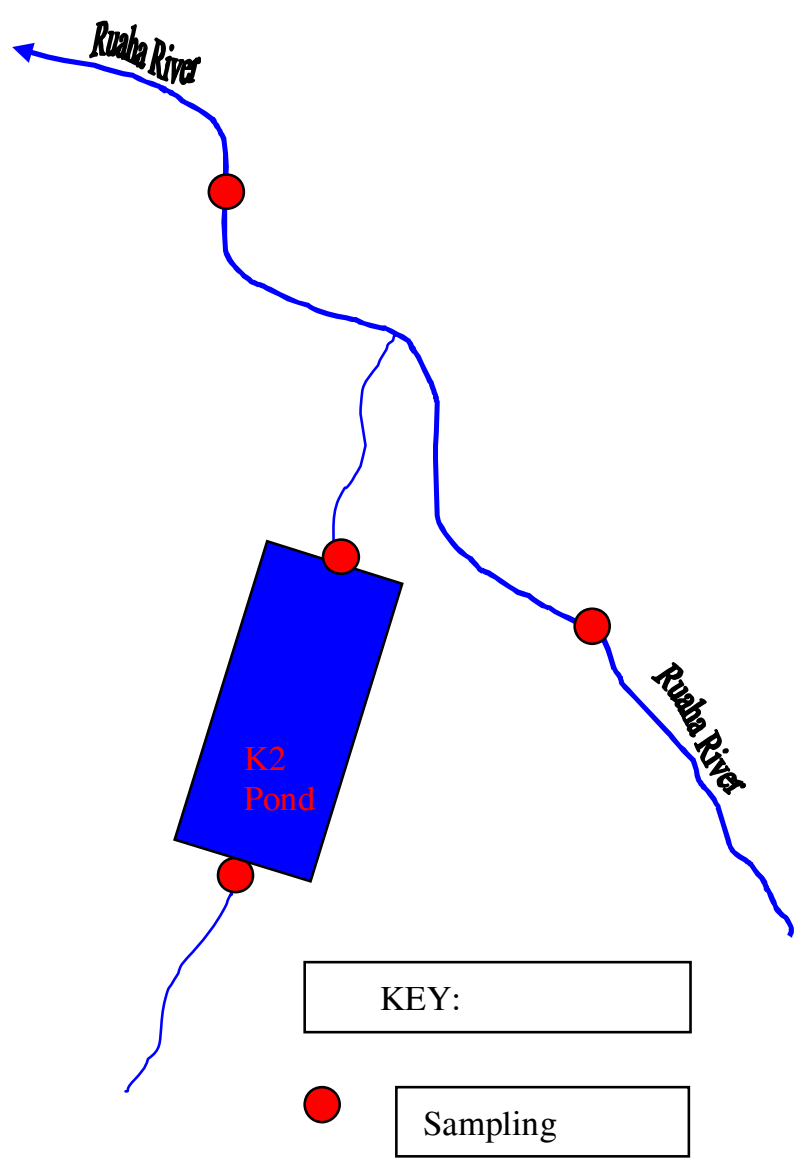

Figure 3: Schematic layout showing sampling locations

Table 2: Analysed parameters and method of analysis used

\begin{tabular}{ll}
\hline Parameter & \multicolumn{1}{c}{ Method of Analysis } \\
\hline $\mathrm{pH}$ & $\begin{array}{l}\text { Inolab WTW } \\
\text { Slow drying followed by } \\
\text { weighing using analytical } \\
\text { Total dissolved solids }\end{array}$ \\
& $\begin{array}{l}\text { APHA plantinum - Cobalt } \\
\text { Color }\end{array}$
\end{tabular}

Turbidity

Ortho phosphate

Hanna Instrument HI 93703 microprocessor

Ascorbic method using Spectronic 20 genesys spectrophotometer.

Nitrate

Devarder's Method

Sulphate

Escherchia coli

Total suspended solids

Spectronic 20 genesys spectrophotometer.

Membrane filtration method Filtration followed by oven drying at $105^{\circ} \mathrm{C}$

$\mathrm{N}, \mathrm{N}-$

Residual Chlorine

diethylparaphenylenediamine (DPD) method

Dissolved Oxygen WTW Multiline F/set P4 universal meter

$\mathrm{BOD}_{5}$

Chemical Oxygen Demand (COD)
Oxi top set up.

Dr Lange ampoules measured by LASA 100 photometer 
Table 3: Water quality from oxidation ponds

\begin{tabular}{|c|c|c|c|c|c|c|c|c|}
\hline \multirow{2}{*}{ Parameters analysed } & \multicolumn{4}{|c|}{ K2 - Influent } & \multicolumn{4}{|c|}{ K2 - Effluent } \\
\hline & Mor. & Noon & Even. & Aver. & Mor. & Noon & Even. & Aver. \\
\hline $\mathrm{pH}$ & 7.58 & 7.25 & 7.04 & 7.29 & 7.04 & 6.95 & 7.03 & 7.01 \\
\hline Turbidity (F.T.U) & 40 & 71 & 64 & 58 & 12 & 11 & 12 & 12 \\
\hline Total Dissolved Solds (mg/l) & 205 & 365 & 360 & 310 & 195 & 150 & 150 & 165 \\
\hline Conductivity $[\mu \mathrm{S} / \mathrm{cm}]$ & 481 & 605 & 412 & 499 & 378 & 382 & 384 & 381 \\
\hline Color (mg Pt.Co/l) & 91 & 91 & 195 & 126 & 51 & 91 & 59 & 67 \\
\hline Total Suspended Solids (mg/l) & 65 & 75 & 725 & 288 & 265 & 80 & 175 & 173 \\
\hline Nitrates (mg/l) & 1.25 & 0.71 & 0.52 & 0.83 & 0.85 & 1.17 & 0.27 & 0.76 \\
\hline Sulphate (mg/l) & 17.24 & 21.61 & 22.29 & 20.38 & 16.09 & 16.78 & 16.09 & 16.32 \\
\hline Ortho Phosphate (mg/l) & 7.10 & 11.30 & 3.85 & 7.42 & 5.60 & 5.10 & 5.15 & 5.28 \\
\hline Residue Chlorine (mg/l) & 0.35 & 0.04 & 0.09 & 0.16 & 0.03 & 0.04 & 0.06 & 0.04 \\
\hline Dissolved Oxygen (mg/l) & 1.70 & 1.08 & 1.47 & 1.41 & 3.39 & 3.33 & 3.50 & 3.40 \\
\hline BOD5 (mg/l) & 65.0 & 79.7 & 82.0 & 75.6 & 27.7 & 33.2 & 63.1 & 41.3 \\
\hline COD (mg/l) & 209 & 307 & 388 & 301 & 91 & 97 & 148 & 112 \\
\hline Escherichia coli (No./100 ml) & $2.3 \mathrm{E}+05$ & $1.6 \mathrm{E}+05$ & $2.1 \mathrm{E}+05$ & $2.0 \mathrm{E}+05$ & $7.0 \mathrm{E}+04$ & $4.0 \mathrm{E}+04$ & $1.1 \mathrm{E}+05$ & 7.3E+04 \\
\hline
\end{tabular}

NOTE: Mor = Morning; Even = Evening;

Aver $=$ Average.

Table 4: Water quality from Ruaha river

\begin{tabular}{|c|c|c|c|c|c|c|c|c|}
\hline \multirow{2}{*}{ Parameters analysed } & \multicolumn{4}{|c|}{ Ruaha river } & \multicolumn{4}{|c|}{ River-k2 mix } \\
\hline & Mor. & Noon & Even. & Aver. & Mor. & Noon & Even. & Aver. \\
\hline $\mathrm{pH}$ & 7.66 & 7.95 & 7.72 & 7.78 & 7.63 & 7.75 & 7.8 & 7.73 \\
\hline Turbidity (F.T.U) & 5 & 5 & 5 & 5 & 5 & 6 & 5 & 5 \\
\hline Total Dissolved Solds (mg/l) & 175 & 225 & 205 & 202 & 170 & 170 & 155 & 165 \\
\hline Conductivity $[\mu \mathrm{S} / \mathrm{cm}]$ & 231 & 233 & 231 & 232 & 235 & 228 & 229 & 231 \\
\hline Color (mg Pt.Co/l) & 22 & 22 & 29 & 24 & 22 & 22 & 22 & 22 \\
\hline Total Suspended Solids (mg/l) & 20 & 40 & 38 & 33 & 36 & 30 & 35 & 34 \\
\hline Nitrates (mg/l) & 1.25 & 0.64 & 0.46 & 0.78 & 1.00 & 0.81 & 0.41 & 0.74 \\
\hline Sulphate (mg/l) & 18.62 & 19.31 & 16.09 & 18.01 & 20.46 & 15.63 & 19.31 & 18.47 \\
\hline Ortho Phosphate (mg/l) & 0.19 & 0.16 & 0.13 & 0.16 & 0.13 & 0.34 & 0.16 & 0.21 \\
\hline Residue Chlorine (mg/l) & 0.17 & 0.09 & 0.03 & 0.09 & 0.03 & 0.11 & 0.21 & 0.12 \\
\hline Dissolved Oxygen (mg/l) & 6.99 & 7.16 & 7.01 & 7.05 & 7.40 & 7.54 & 7.10 & 7.35 \\
\hline BOD5 (mg/l) & 7 & 6 & 5 & 6 & 6 & 4 & 4 & 5 \\
\hline $\mathrm{COD}(\mathrm{mg} / \mathrm{l})$ & 37 & 21 & 15 & 24 & 10 & 12 & 15 & 13 \\
\hline Escherichia coli (No./100 ml) & 72 & 97 & 110 & 93 & 285 & 366 & 714 & 455 \\
\hline
\end{tabular}

NOTE: Mor = Morning; Even = Evening;

Aver $=$ Average. 


\section{Configuration Analysis of the Ponds}

The analysis of pond configuration is an attempt to re-design the current wastewater stabilization pond in Kilombero Sugar Company so as the discharged effluent into receiving water bodies is of acceptable standard. In this study, two systems were considered. The FM and AFM systems as discussed in detail below

\section{Facultative Pond Plus Maturation Pond System}

(a) Facultative Pond

The main purpose of facultative pond is the BOD reduction. It is assumed that the pond is a completely mixed reactor in which $\mathrm{BOD}_{5}$ removal follows the first order kinetics [1].

$$
\frac{L e}{L i}=\frac{1}{1+k_{1} t}
$$

Where $\mathrm{Li}=\mathrm{BOD}_{5}$ in the influent in $\mathrm{mg} / \mathrm{l}$

$\mathrm{Le}=\mathrm{BOD}_{5}$ in the effluent in $\mathrm{mg} / \mathrm{l}$

$\mathrm{t}=$ retention time in days

$\mathrm{K}_{1}=$ first order rate constant for BOD removal in $\mathrm{d}^{-1}$

\section{Retention time $(t)$}

$$
t=\frac{A x H}{Q}
$$

Where $\mathrm{A}=$ Pond surface area at the middle

$\mathrm{H}$ is the depth

$\mathrm{Q}=$ waste water flow in $\mathrm{m}^{3} /$ day

The area $(\mathrm{A})$ is given by

$$
A=\frac{Q}{H x k_{1}}\left(\frac{L i}{L e}-1\right)
$$

Values of $\left.\mathrm{K}_{1}=0.3 \times 1.05\right)^{(\mathrm{T}-20)}$

Depths of 1.0 to $1.5 \mathrm{~m}$ are generally used.

$\mathrm{H}=1.2 \mathrm{~m}$

$\mathrm{Li}=200 \mathrm{mg} / \mathrm{l}$

$\mathrm{Le}=30 \mathrm{mg} / 1$

$\mathrm{Q}=600.56 \mathrm{~m}^{3} / \mathrm{d}$

$\mathrm{A}=600.56 \mathrm{x}\{(200 / 30)-1\} /(1.2 \times 0.3)=9453.3 \mathrm{~m} 2=0.95 \mathrm{ha}$

$\mathrm{D}=$ Retention time $\mathrm{t}=9453.3 \times 1.2 / 600.56=18.9$ days.

It is recommended that a minimum retention time of 7 days should be used for individual ponds because of short circuiting in ponds with shorter retention time [1, 5]. Sufficiently long retention time of about 5-10 days should be allowed.

(b) Maturation pond

Maturation ponds are designed to achieve bacterial removal as a final step after $\mathrm{BOD}_{5}$ has been reduced in the anaerobic and facultative ponds. Facultative can also remove the bacteria.

$$
N e=\frac{N i}{\left[1+K_{b} t_{f}\right]\left[1+K_{b}(T) t_{m}\right]^{n}}
$$

Where, $\mathrm{Ne}$ and $\mathrm{Ni}$ are number of E-coli per $100 \mathrm{ml}$ in the influent and effluents respectively.

$\mathrm{K}_{\mathrm{b}}(\mathrm{T})=2.6 \mathrm{x}(1.19)^{\mathrm{T}-20}$ in all ponds

For the design purposes a value of 200mg/l BOD5 (average strength) inlet is assumed and an outlet to be fixed at $30 \mathrm{mg} / \mathrm{l}$. E-coli was established to be $2.0 \times 10^{6}$ per $100 \mathrm{ml}$ in the influent (normally influent can contain up to $10^{9}$ E-coli per $100 \mathrm{ml}$. For receiving stream it is required that the E-coli should be less than 1,000 per $100 \mathrm{ml} . \mathrm{K}_{\mathrm{b}}$ is E-coli removal rate constant; $t_{f}$ is the retention time in the facultative pond; $t_{m}$ retention time in one maturation pond usually 5-7 days.

$$
1000=\frac{2.0 \times 10^{6}}{[1+2.6 \times 18.9][1+2.6 \times 7]^{n}}
$$

From above equation $\mathrm{n}=1.2$, minimum $\mathrm{n}$ should be equal to 2 ;

Thus the required number of maturation ponds for $\mathrm{K} 2$ facility is $n=2$;

Maturation pond volume $=7$ days $\times 600.56 \mathrm{~m} 3 /$ day $=$ $4203.9 \mathrm{~m}^{3}$

For a depth of $1.2 \mathrm{~m}$ the mid pond area is $4203.9 / 1.2=$ $3503.3 \mathrm{~m}^{2}=0.35 \mathrm{ha}$.

Total area coverage for three (3) ponds is $0.95 \mathrm{ha}+$ $0.35 \mathrm{ha}+0.35 \mathrm{ha}=1.65 \mathrm{ha}$.

\section{Anaerobic, Facultative and Maturation system}

\section{(a) Anaerobic pond}

Anaerobic ponds should be designed mainly on the basis of volumetric organic loading $\left(\right.$ g. $\left.\mathrm{BOD}_{5} / \mathrm{m}^{3} / \mathrm{d}\right)$ but detention time should also be taken into account. Anaerobic ponds are designed to receive BOD loadings between $100-400 \mathrm{~g} . \mathrm{BOD}_{5} / \mathrm{m}^{3} / \mathrm{d}$. The actual loading will depend on climate, with higher loadings possibility at higher temperatures. The hydraulic detention time is usually between 2.5-5 days and the rate of BOD removal is between $50-80 \%[1,2,5]$. Normally $60 \%$ volumetric loading is given by:

$$
v=\frac{L_{i} Q}{V}
$$

Where $\mathrm{v}=$ Volumetric loading g. $\mathrm{BOD}_{5} / \mathrm{m}^{3} /$ day $\mathrm{Li}=$ Inflow BOD5 concentration in $\mathrm{mg} / \mathrm{l}$

$\mathrm{Q}=$ Influent flow rate in $\mathrm{m}^{3} / \mathrm{d}$;

$\mathrm{V}=$ Volume of the pond in $\mathrm{m}^{3}$;

Depth of the pond is usually between 2.5 and $5.0 \mathrm{~m}$;

The BOD load $=200 \mathrm{mg} / 1 \times 600.56 \mathrm{~m}^{3} \times 10001 / \mathrm{m}^{3} /$ day $=$ $120.1 \mathrm{Kg} /$ day;

Assuming a volumetric loading of $200 \mathrm{~g} . \mathrm{BOD}_{5} / \mathrm{m}^{3} /$ day; Then the required volume $=(120.1 / 200) \times 1000=600.5$ $\mathrm{m}^{3}$; Thus retention time $=600.5 / 600.56=1.0$ days .

Taking the depth to be $4.0 \mathrm{~m}$ then the area at the midpond depth is $600.56 / 4=150.1 \mathrm{~m}^{2}(0.015 \mathrm{ha})$. 
(b) Facultative pond

$60 \%$ of BOD is removed in the anaerobic pond the remaining BOD is $200(1-0.60)=80 \mathrm{mg} / \mathrm{l}$ as $\mathrm{Li}$ and $\mathrm{Le}=$ $30 \mathrm{mg} / \mathrm{l}$. Thus the area of the facultative pond becomes:

$$
A=\frac{Q}{H x k_{1}}\left(\frac{L i}{L e}-1\right)
$$

$\mathrm{A}=600.56 \times(80 / 30-1) /(1.2 \times 0.3)=2780.4 \mathrm{~m}^{2}=0.28 \mathrm{ha}$ Detention time $\mathrm{t}=2780.4 \times 1.2 / 600.56=5.6$ days

\section{(c) Maturation pond}

Bacteria will be removed in all of the ponds. Anaerobic and facultative can also remove the bacteria though in the anaerobic pond the removal is about half way:

$$
N e=\frac{N i}{\left[1+\left(\frac{K_{b}}{2} t_{a}\right)\right]\left[1+K_{b} t_{f}\right]\left[1+K_{b}(T) t_{m}\right]^{n}}
$$

$K_{b}(T)=2.6 x(1.19)^{T-20}$ in all ponds;

Where $\mathrm{Ne}$ and $\mathrm{Ni}$ are number of E-coli per $100 \mathrm{ml}$ in the influent and effluents respectively;

$\mathrm{K}_{\mathrm{b}}$ is E-coli removal rate constant

$\mathrm{t}_{\mathrm{a}}$ is the retention time in anaerobic pond

$t_{f}$ is the retention time in the facultative pond

$\mathrm{t}_{\mathrm{m}}$ retention time in one maturation pond usually 5-7 days.

Thus taking $\mathrm{n}=1$ :

$$
N e=\frac{2 \times 10^{6}}{\left[1+\left(\frac{2.6}{2} \times 2\right)\right][1+2.6 \times 5.6][1+2.6 \times 7]}=1,891
$$

The value obtained is above 1,000 thus providing TWO maturation ponds as above each with mid-pond area of 0.35 ha.

Total area coverage for four (4) ponds is $(0.015+$ $0.28+0.35+0.35)=0.995$ ha

\section{Configuration and Sizes Required for Proper Function of the Pond}

The result of the calculations in revealing the existing configuration, layout and design of the oxidation ponds in $\mathrm{K} 2$ shows that the ponds are neither Facultative Maturation system (FMS) nor Anaerobic Facultative Maturation system (AFMS). This has been illustrated by a review design calculation above. The review design calculation shows configuration indicated in Table 5 for the proper functioning of the ponds. The layout would be

\begin{tabular}{|c|c|c|c|c|c|}
\hline \multicolumn{3}{|c|}{ Facultative - Maturation } & \multicolumn{3}{|c|}{$\begin{array}{c}\text { Anaerobic - Facultative - } \\
\text { Maturation }\end{array}$} \\
\hline Chamber & $\begin{array}{c}\text { Area } \\
\text { (ha) }\end{array}$ & $\begin{array}{c}\text { Depth } \\
(m)\end{array}$ & Chamber & $\begin{array}{c}\text { Area } \\
(h a)\end{array}$ & $\begin{array}{c}\text { Depth } \\
(m)\end{array}$ \\
\hline $\begin{array}{l}\text { Facultative } \\
\text { (WSP) }\end{array}$ & 0.95 & 1.2 & $\begin{array}{c}\text { Anaerobic } \\
\text { (WSP) }\end{array}$ & 0.15 & 3.0 \\
\hline $\begin{array}{l}\text { Maturation } \\
\text { (WSP) }\end{array}$ & 0.35 & 1.2 & $\begin{array}{c}\text { Facultative } \\
\text { (WSP) }\end{array}$ & 0.28 & 1.2 \\
\hline \multirow[t]{2}{*}{$\begin{array}{l}\text { Maturation } \\
\text { (WSP) }\end{array}$} & 0.35 & 1.2 & $\begin{array}{c}\text { Maturation } \\
\text { (WSP) }\end{array}$ & 0.35 & 1.2 \\
\hline & & & $\begin{array}{l}\text { Maturation } \\
\text { (WSP) }\end{array}$ & 0.35 & 1.2 \\
\hline $\begin{array}{l}\text { Total are } \\
\text { (ha) }\end{array}$ & 1.65 & & & 0.995 & \\
\hline
\end{tabular}
as shown in Figures 4 and 5.
Table 5: Supposed sizes of oxidation pond

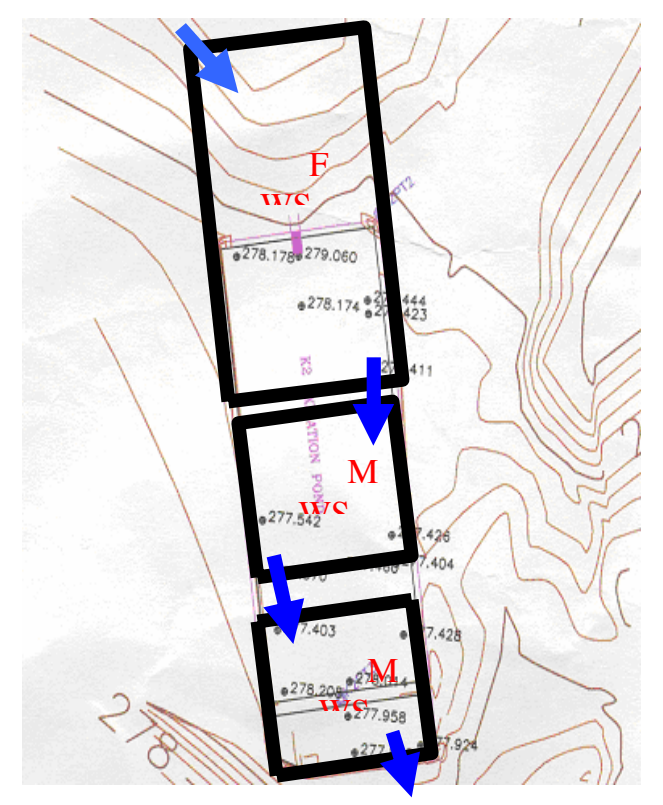

Figure 4: Layout of the K2 pond with FM system

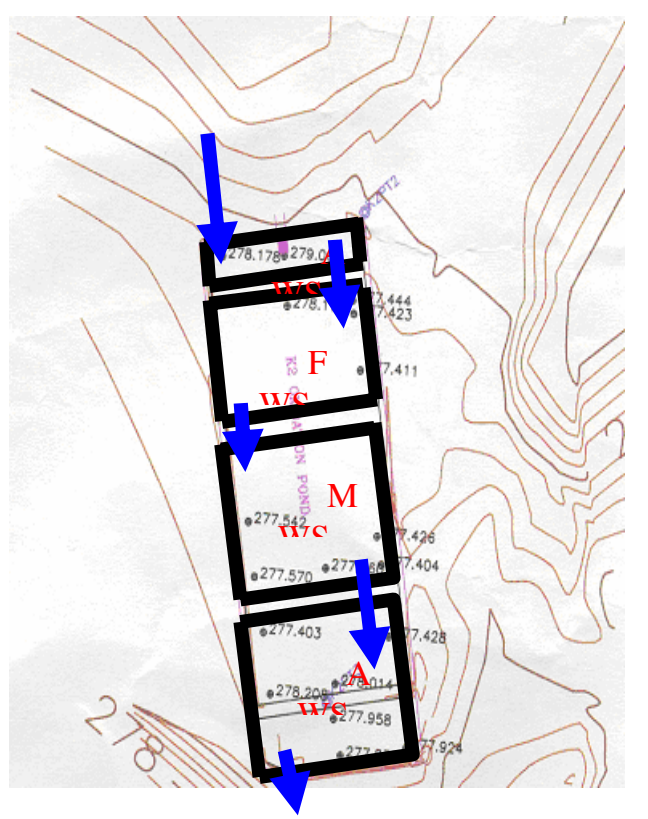

Figure 5: Layout of the K2 pond with AFM system 


\section{Discussion of the Results}

Before the design options was made for the waste water treatment, the water quality samples were analyzed first. The main parameters looked at were the bacterial quality, BOD loads and residual chlorine status. These could give pollution levels in the environment [7-9]. The Ruaha river was found to be polluted even before the ponds effluents thus there are more polluters upstream. The existing pond system was not functioning properly as the effluents were of poor quality when compared with the standards [10-12, 14], requiring the need for new system design. The BOD load variation was quite remarkable for morning hours and evening hours. During the evening most of the workers are at home and thus produce more pollution during this time of the day. This paper provides five points which are supposed to discuss the results as fully as possible. These are given below:

1 The Ruaha River is not safe bacteriologically even before the influence of the effluent from the Sugar Company as some levels of bacteria are observed. For drinking water without disinfection or boiling, the recommended standard is ZERO/100ml.
2 Though there is a reduction in the number of E.Coli between influent and effluent still the levels at the ponds outlets are quite high indicating that the ponds are not adequately removing the bacteria. For immediate raw re-use by the villagers located just downstream, after the effluent has joined the river, the number should not exceed 200/100ml.

3 BOD5 from K2 effluents which has a maximum of $63.1 \mathrm{mg} / \mathrm{l}$ experienced in the evenings might be the results of the attendants who was harvesting water hyacinths in the evening and this might have affected the results) but generally effluents from the $\mathrm{K} 2$ ponds are of the order 27.7 and $33.2 \mathrm{mg} / \mathrm{l}$ which is a bit high to be discharged into the receiving water body (Tables $3 \& 6$ ).

4 The general trend has shown that there are more BODs during the evenings compared to the rest of time. This is an indication that the peak hour is in the evening.

5 Highest recorded residual chlorine is $0.47 \mathrm{mg} / \mathrm{l}$ in the evening but in other cases the residual chloride is quite low indicating a proper disinfectants management (Table 7).

Table 6: Key Water Quality Parameters Levels

\begin{tabular}{lcccc}
\hline \multirow{2}{*}{ Parameter } & \multicolumn{2}{c}{ Acceptable/permissible } & \multicolumn{2}{c}{ Allowable/excessive } \\
\cline { 2 - 5 } & Tanzania m/l & WHO $m g / 1$ & Tanzania mg/l & WHO mg/l \\
\hline Total Solids & N.M. & 500 & N.M. & 1500 \\
Iron $(\mathrm{Fe})$ & 0.3 & 0.3 & N.M. & 1.5 \\
Manganese $(\mathrm{Mn})$ & 0.5 & 0.1 & 1.5 & 0.5 \\
Calcium $(\mathrm{Ca})$ & N.M. & 75 & N.M. & 200 \\
Sulphate $\left(\mathrm{SO}_{4}\right)$ & N.M & 200 & 600 & 400 \\
Chloride $(\mathrm{C} 10$ & N.M. & 200 & 800 & 600 \\
Fluoride $(\mathrm{F})$ & 2.0 & 1.5 & 8.0 & 2.0 \\
Nitrate $\left(\mathrm{NO}_{3}\right)$ & 100 & 30 & N.M. & N.M. \\
BOD5 $*$ & 30 & 6 & 60 & 10 \\
Coliform bacteria per 100 & N.M. & N.M. & 600 & N.M. \\
ml & & & &
\end{tabular}

*Effluents to be discharged directly into receiving water body

Table 7: Determinants with aesthetic/physical implications

\begin{tabular}{|c|c|c|c|c|c|}
\hline \multirow{2}{*}{ Determinants } & \multirow{2}{*}{ Units } & \multicolumn{4}{|c|}{ Limits For Groups } \\
\hline & & $A$ & $B$ & $C$ & $D^{*}$ \\
\hline Colour & & 30 & - & - & - \\
\hline Conductivity & $\mu \mathrm{S} / \mathrm{cm}$ & 1500 & 3000 & 4000 & 4000 \\
\hline Total hardness & $\mathrm{mg} / \mathrm{CaCO}_{3}$ & 300 & 650 & 1300 & 1300 \\
\hline Turbidity & F.T.U & 1 & 5 & 10 & 10 \\
\hline Chloride & $\mathrm{mg} / \mathrm{l} \mathrm{Cl}$ & 250 & 600 & 1200 & 1200 \\
\hline Chlorine (free) & $\mathrm{mg} / \mathrm{l} \mathrm{Cl}$ & $0,1-5,0$ & $0,1-5,0$ & $0,1-5,0$ & 5,0 \\
\hline Fluoride & $\mathrm{mg} / \mathrm{l} \mathrm{F}$ & 1,5 & 3,0 & 3,0 & 3,0 \\
\hline Sulphate & $\mathrm{mg} / \mathrm{l} \quad \mathrm{SO}_{4}$ & 200 & 1200 & 1200 & 1200 \\
\hline Copper & $\mu \mathrm{g} / \mathrm{ll} \mathrm{Cu}$ & 500 & 2000 & 2000 & 2000 \\
\hline Nitrate & $\mathrm{mg} / \mathrm{l} \quad \mathrm{N}$ & 10 & 40 & 40 & 40 \\
\hline Hydrogen Sulphide & $\mu \mathrm{g} / \mathrm{l} \quad \mathrm{H}_{2} \mathrm{~S}$ & 100 & 600 & 600 & 600 \\
\hline Iron & $\mu \mathrm{g} / \mathrm{l} \quad \mathrm{Fe}$ & 100 & 2000 & 2000 & 2000 \\
\hline Manganese & $\mu \mathrm{g} / \mathrm{Mn}$ & 50 & 2000 & 2000 & 2000 \\
\hline Zinc & $\mathrm{mg} / \mathrm{l} \quad \mathrm{Zn}$ & 1 & 10 & 10 & 10 \\
\hline pH & $\mathrm{pH}$-unit & $6,0-9,0$ & $4,0-11,0$ & $4,0-11,0$ & $4,0-11,0$ \\
\hline
\end{tabular}

Group A: Water with an excellent quality; Group B: Water with good quality; Group C: Water with low health risk;

Group D: Water with a higher health risk or water unsuitable for human consumption 


\section{Conclusion}

The design of the waste water stabilization pond in $\mathrm{K} 2$ is not in accordance with specification standards defined in different design books and manuals and that is why it does not produce effluent of acceptable standards in receiving bodies. A review and its proposed re-design for proper functioning of the existing stabilization ponds have been conducted and design options suggested in this paper.

In most developing countries like Tanzania, the low effluent which is discharged into receiving bodies and their effect to the downstream communities will need more investigation particularly on ways in which the effect can be minimized. There exists a number of water quality models that can trace the fate and transport of pollutants once discharged into the receiving water bodies. The impact of pollution can then be established to know the distance down stream to which pollution is still experienced. Application of models such as these will allow the governing authorities to advise the communities of where they should collect water. Also this can even optimize the pond design in terms of size, which can save cost.

In addition, studies of relation between water levels in receiving bodies and their relative level of pollutant can help in decision making by governing authorities to advise the communities living in the downstream to treat the water before using them at critical levels of pollution. Alternatively, the water collection point can be defined according to the seasonal calendar and or flow levels in receiving bodies.

\section{References}

1. ITECO: Final Report on design of the configuration of $\mathrm{K} 2$ oxidation pond, sewage network in block "A" hauses, Kantui school and the Mkamba cane cutter camp, Main report, 2004, 19 pp.

2. ITECO: Phase I technical report on the studies to improve the drainage and sewage system of the Kilombero Sugar Company, K1 and K2 sides, 2004, 24pp.

3. COWI: Study of waste water systems at Kilombero Sugar Company Limited - K1 and K2 factories Kidatu, Tanzania, 2003, 61pp.
4. ITECO: Phase I technical report on the studies to improve the drainage and sewage system of the Kilombero Sugar Company, K1 and K2 sides, ANNEX 9, 2004, 7pp.

5. Mara Duncan: Design Manual for WASTE STABILIZATION PONDS in India, Lagoon Technology International Limited, University of Leads, England, 1997, 125pp.

6. American Public Health Association. Standard methods for the analysis of water and wastewater, $19^{\text {th }}$ edition. American Public Health Association, Washington DC. APHA, 1995.

6 Bartram, J.; Balance editors. Water quality monitoring - A practical guide to the design and implementation of freshwater quality studies and monitoring programes. $1^{\text {st }}$ edition. London: Chapman and Hall, 1996.

7. Chapman \& Hall: Water Quality assessments - A guide to the use of biota, sediments and water in environmental monitoring. $2^{\text {nd }}$ Edition. London: Chapman and Hall. London, 1996.

8. Sundbland, K., Tonderski, A., Rulewski, J.: Nitrogen and Phosphorus in the Vistula River, Poland - Changes from sources to mouth. Journal of Water Science and Technology. 1994, 30: 177-186.

9. World Health Organization (WHO). Guidelines for drinking-water quality, 2nd ed. Vol. 2. Health criteria and other supporting information. Geneva, 1996. pp. 370-373.

10. World Health Organization (WHO): Water Quality: Guidelines, Standards and Health. 2001.

11. WRC. Water Research Commission No. TT101. Quality of domestic water supply. Volume1: Assessment Guide, 1998.

12. Wu, C.; Maurer, C.; Wang, Y.; Xue, S.; Davis, D. L.: Water Pollution and Human Health in China. In: The Journal of the National Institute of Environmental Health Sciences. Environmental Health Perspectives, 1999, 107 (4): 251-256.

13. Hammer, M. J.: Water and Wastewater Technology. SI Version. John Wiley \& Sons, INC, New York. 1975. 